\title{
Upaya Peningkatan Kemampuan Guru dalam Merancang Instrumen Tes Melalui Pelatihan Terintegrasi Self Assessment
}

\author{
Olimpia Sitio \\ SDN 144/V Betara Kiri, Kec. Kuala Betara, Kab. Tanjung Jabung Barat, Provinsi \\ Jambi, Indonesia \\ Email: olimpia.sitio@yahoo.com
}

\begin{abstract}
Abstrak: Proses penilaian merupakan hal yang tidak dapat terpisahkan dari proses pembelajaran. Kevalidan simpulan dari hasil penilaian sangat bergantung pada proses dan kualitas instrumen tes. Namun di SDN 144/V Betara Kiri, Kabupaten Tanjung Jabung Barat guru-guru tidak pernah mengembangkan instrumen tes untuk proses penilaian. Penelitian Tindakan Sekolah (PTS) ini bertujuan untuk meningkatkan kemampuan 8 guru SDN 144/V Betara Kiri dalam merancang instrumen tes. Pelatihan dilakukan dengan mengintegrasikakn self assessment. Data yang dikumpulkan berupa data kuantitatif dari hasil validasi ahli dan kualitatif dari hasil wawancara dan masukan oleh validator. Hasil penelitian menunjukkan bahwa
\end{abstract}

\begin{tabular}{l}
\hline Tersedia Online di \\
\hline http://journal.unublitar.ac.id/pendidika \\
n/index.php/Riset_Konseptual \\
\hline Sejarah Artikel \\
\hline Diterima pada : 08-04-2020 \\
Disetuji pada : 24-04-2020 \\
Dipublikasikan pada : 30-04-2020 \\
\hline Kata Kunci: \\
\hline Instrumen Tes; Pelatihan; Self Assessment; \\
DOI: \\
http://doi.org/10.28926/riset_konseptual.v4i2. \\
219
\end{tabular}

kemampuan guru dalam merancang instrumen tes mengalami peningkatan yang diindikasikan dari peningkatan rata-rata skor yakni dari 83,45 menjadi 89,75. Berdasarkan hasil wawancara, guru-guru memberikan pendapat bahwa self assessment berguna dalam membantu pemahaman mereka.

\section{PENDAHULUAN}

Penilaian merupakan hal yang tidak dapat dipisahkan dari pembelajaran (Muchtar, 2010; Pantiwati, 2016; Setiawan, 2013; Zahro, 2015). Penilaian merupakan salah satu pengukur keberhasilan guru dalam merancang dan melaksanakan kegiatan pembelajaran. Penilaian terdiri dari serangkaian proses atau kegiatan pengumpulan dan pengolahan informasi untuk mengukur keberhasilan siswa dalam mencapai hasil belajar (Salamah, 2018).

Penilaian sendiri dapat dilakukan dengan tes maupun non tes (Arifin, 2012) Kedua penilaian tersebut tepat dengan masing-masing kondisi. Bagaimanapun cara guru dalam melakukan penilaian pada prinsipnya tetap bertujuan untuk menghimpun informasi sebanyak mungkin terhadap perkembangan peserta didik. Informasiinformasi yang telah berhasil dihimpun sangat berguna untuk menentukan tindakan yang paling baik dalam untuk memaksimalkan capaian pembelajaran.

Salah satu teknik penilaian yang sering digunakan adalah dengan tes dengan jenis tes pilihan berganda (Bhakti et al., 2017; Rahmawati et al., 2020). Tes pilihan berganda ini setidaknya harus memenuhi kriteria tingkat validitas dan reliabilitas yang memadai agar set instrumen tes dapat dikatakan layak (Abdul Kadir, 2015; Amalia \& Widayati, 2012; Handayani \& Ambar, 2015; Matondang, 2009). Disamping valid dan reliabel, kriteria tingkat kesukaran dan daya pembeda soal juga perlu diperhatikan. Definisi valid dan reliabel merupakan hal yang harus dipahami oleh guru. Bagaimana guru mengambil informasi dari siswa hingga memberi klaim terhadap kompetensi siswa sangat bergantung pada instrumen yang digunakan. Kesimpulan yang baik harus didasarkan pada instrumen tes yang baik dan pengambilan data yang baik pula. 
Tanpa keduanya maka proses penilaian pembelajaran tidak akan terselesaikan dengan baik dan benar.

Selama ini guru-guru di SDN 144/V Betara Kiri Kabupaten Tanjung Jabung Barat tidak pernah mengembangkan instrumen tes yang digunakan untuk mengukur capaian hasil belajar siswa. Soal-soal yang digunakan selama ini dibuat oleh guru ketika mendekati pelaksanaan ujian atau ulangan sehingga tidak pernah dilakukan analisis validitas dan reliabilitas instrumen tes. Guru lebih sering membuat soal dengan mengadaptasi dari berbagai sumber seperti buku dan internet. Selain itu guru-guru juga tidak memperhatikan level kognitif yang diukur sehingga beberapa soal tidak cocok untuk standar kompetensi yang harus dicapai.

Permasalahan tersebut tentu memerlukan tindakan agar dapat teratasi atau minimal dapat tereduksi. Dalam memecahkan permasalahan yang terjadi pada guruguru sebenarnya perlu keterbukaan. Masing-masing guru bisa saja memiliki masalah yang berbeda-beda. Oleh karenanya diperlukan self-assessment untuk mengetahui hal-hal yang telah dan belum dipahami dengan baik oleh guru.

Self assessment pada dasarnya merupakan salah satu teknik penilaian yang dilakukan oleh siswa sebagai individu yang dinilai sekaligus penilai. Jika dilihat dari model tradisional penilaian, maka self assessment sebenarnya merupakan bagian dari penilaian formatif (formative assessment) namun bukan dilakukan oleh guru melainkan oleh siswa (Wilujeng, 2014). Penerapan self assessment ini memiliki beberapa kelebihan yakni mampu menumbuhkan rasa percaya diri pada siswa, dapat memicu kesadaran akan kekurangan dan kekuatan siswa, dan mampu mendorong siswa untuk lebih jujur (Purnamah, Nuryana, \& Puspitasari, 2017). Kendati demikian self assessment ini masih jarang diterapkan dalam pembelajaran maupun kegiatan pelatihan dalam konteks pendidikan (Nurhardini, 2017). Hal tersebut dikarenakan masih ada beberapa pengajar yang khawatir jika penerapan self assessment menghasilkan data yang overestimate dan subjektif (Wahyuningsih, Wahyuni, \& Lesmono, 2016). Namun hal tersebut dapat diatasi dengan menggunakan penilaian yang dilakukan oleh guru untuk mendukung data self assessment.

Dalam penelitian ini self assessment bukan bertujuan untuk memberikan nilai kepada guru selama proses pelatihan namun untuk menggali kekurangan dan kelebihan untuk memaksimalkan hasil pelatihan yang dilaksanakan. Dengan menerapkan self assessment maka diharapkan akan lebih mudah menunjukkan permasalahan-permasalahan yang masih terjadi pada guru sehingga dengan segera untuk diberikan tindakan. Dalam penelitian ini dilakukan kegiatan pelatihan untuk guruguru dalam merancang intumen tes.

\section{METODE}

Penelitian ini merupakan penelitian tindakan sekolah. Penelitian ini dilakukan atas dasar permasalahan yang terjadi di lingkungan sekolah. Penelitian dilakukan dalam dua siklus. Setiap siklus mengikuti tahapan-tahapan yang dikembangkan oleh Kemmis, McTaggart, \& Nixon (2014). Adapun kegiatan yang dilakukan dalam penelitian untuk tiap siklus adalah perencanaan, tindakan, observasi, dan refleksi. Perencanaan yang dilakukan pada siklus I didasarkan atas temuan pada identifikasi masalah sedangkan pada siklus II perencanaan perbaikan didasarkan pada hasil refleksi. Untuk lebih jelasnya, skema penelitian tindakan sekolah seperti yang ditunjukkan Gambar 1. 


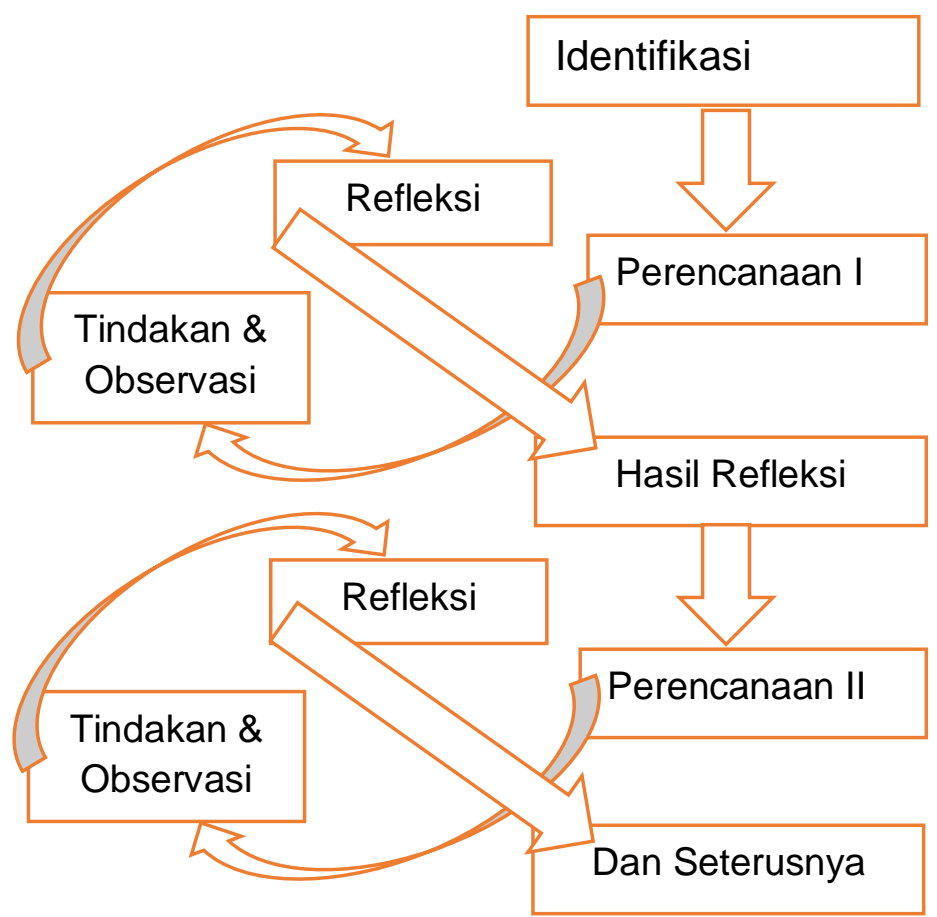

Gambar 1. Skema Penelitian Tindakan Sekolah

Penelitian tindakan sekolah ini dilaksanakan di SDN 144/V Betara Kiri Kabupaten Tanjung Jabung Barat. Subjek penelitian merupakan guru-guru yang terdiri dari 8 guru dengan 5 guru laki-laki dan 3 guru perempuan. Penelitian ini dilaksanakan pada Tahun Ajaran 2019/2020 semester ganjil. Penelitian dilakukan selama 6 bulan mulai dari perencanaan hingga analisis data.

Pelaksanaan penelitian dilakukan melalui kegiatan pelatihan dengan pemberian materi terkait penilaian hasil belajar siswa yang difokuskan pada instrumen tes. Guru-guru diberi pembekalan terkait (1) Dasar-dasar penilaian dengan membedakan secara detail terkait evaluasi, penilaian, pengukuran, dan tes dan nontes; (2) Prinsip-prinsip penyusunan soal dalam format pilihan berganda; (3) Analaisis validitas, reliabilitas, daya pembeda, dan tingkat kesukaran soal; dan (4) Penyusunan kisi-kisi soal. Pelaksaan penelitian dilakukan dengan melaksanakan pelatihan tatap muka untuk menyampaikan materi, kemudian guru bekerja secara mandiri selama 2 minggu untuk menyelesaikan instrumen tes. Instrumen yang telah disusun kemudian dinilai oleh validator. Setelah dinilai oleh validator, instrumen dikembalikan kepada masing-masing guru. Pada siklus kedua pelaksanaan penelitian dilakukan dengan langkah yang sama namun mengembangkan instrumen baru, bukan memperbaiki instrumen yang telah divalidasi.

Dalam penelitian ini guru diwajibkan untuk menyusun kisi-kisi instrumen tes sesuai dengan mata pelajaran yang dipilih oleh masing-masing guru. Berdasarkan kisikisi yang dibuat oleh guru, akan dinilai beberapa aspek yang menunjukkan kemampuan guru dalam merancang soal. Penilai merupakan 2 dosen pendidikan dari Universitas Jambi yang merupakan ahli assessment pendidikan dasar.

Data penelitian yang dikumpulkan merupakan data kuantitatif dan data kualitatif yang diperoleh dari lembar penilaian oleh validator pada kisi-kisi instrumen tes. Terdapat 3 aspek yang dinilai dari kisi-kisi soal yang dibuat oleh guru-guru. Aspek pertama adalah isi. Aspek isi memiliki 4 indikator yakni (1) kesesuaian indikator soal dengan standar kompetensi (SK) dan kompetensi dasar (KD); (2) kesesuaian soal dengan indikator soal; (3) kesesuaian kunci dengan konsep; dan (4) kesesuaian soal dengan level kognitif yang diukur. Aspek kedua adalah konstruk soal. Aspek konstruk soal memiliki 2 indikator yakni (1) pengecoh jawaban pada soal baik dan berguna; dan (2) pertanyaan soal tidak mengarahkan siswa pada jawaban benar. Aspek terakhir 
yakni bahasa. Aspek bahasa memiliki 2 indikator yakni (1) bahasa yang digunakan lugas, padat, dan jelas; dan (2) bahasa yang digunakan sudah memenuhi ketentuan Pedoman Umum Ejaan Bahasa Indonesia (PUEBI).

Data yang diperoleh dari lembar penilaian validator menggunakan skala likert yang dikonversi menjadi skor dengan maksimal 100 yang diinterpretasikan sebagai nilai validasi kisi-kisi instrumen soal. Konversi skala likert ke skor yang diinterpretasikan sebagai nilai validasi kisi-kisi intrumen soal dilakukan dengan menggunakan rumus berikut.

$$
\text { Validitas }=\frac{\text { Total skor dari } 2 \text { validator }}{\text { Skor maksimal }} \times 100
$$

Skor yang diperoleh dari persamaan tersebut kemudian diinterpretasikan ke dalam kriteria validitas. Kriteria tersebut seperti yang ditunjukkan pada Tabel 1.

Tabel 1. Kriteria Validitas untuk Kisi-Kisi Intrumen Soal yang Dirancang

\begin{tabular}{lll}
\hline No & Skor & Kriteria \\
\hline 1 & $85,01-100,00$ & Sangat valid \\
2 & $70,01-85,00$ & Cukup valid \\
3 & $50,01-70,00$ & Kurang Valid \\
4 & $0,00-50,00$ & Tidak valid \\
\hline
\end{tabular}

(Sumber: Akbar, 2013)

Data kualitatif diperoleh dari kegiatan observasi selama pelatihan. Selain itu, data kualitatif juga diperoleh dari kegiatan wawancara. Wawancara dilakukan dengan memfokuskan pada pertanyaan terkait kegunaan kegiatan pelatihan terhadap peningkatan kemampuan guru dalam membuat instrumen tes. Kegiatan wawancara dilakukan pada guru-guru peserta pelatihan. Selain itu data kualitatif juga diperoleh dari masukan yang diberikan oleh validator dalam menilai instrumen tes yang telah disusun oleh guru.

Paparan hasil dalam artikel ini disajikan tabel data statistik deskriptif untuk menceritakan karakteristik kemampuan guru-guru dalam merancang instrumen tes yang berkualitas. Selain itu akan dipaparkan pula data persentase kemampuan guru dalam merancang instrumen tes berdasarkan kriteria kevalidan.

\section{Data Statistik Deskriptif Skor Validasi Ahli}

\section{HASIL dan PEMBAHASAN}

Skor yang diperoleh dari validasi oleh dua validator yang telah dikonversi pada skala maksimal 100 dipaparkan dalam statistik deskriptif untuk memberikan gambaran umum perubahan kemampuan guru dalam membuat instrumen tes. Data statistik deskriptif yang dipaparkan berupa jumlah guru, rata-rata, modus, median, dan standar deviasi. Data statistik deskriptif tersebut seperti yang ditunjukkan pada Tabel 2.

Tabel 2. Data Statistik Deskriptif Skor Validasi Ahli

\begin{tabular}{lll}
\hline Statistik Deskriptif & Siklus I & Siklus II \\
\hline $\mathrm{N}$ & 8 & 8 \\
\hline Rata-Rata & 83,45 & 89,75 \\
\hline Modus & 82,50 & 88,67 \\
\hline Median & 83,00 & 88.25 \\
\hline Standar Deviasi & 7,08 & 11,54 \\
\hline
\end{tabular}


Berdasar data pada Tabel 2 tampak bahwa kemampuan guru dalam membuat instrumen tes mengalami peningkatan. Berdasarkan rata-rata skor sebagai ukuran tendency central yang paling representatif menunjukkan bahwa pada siklus I sebesar 83,45 kemudian meningkat sebesar 6,3 menjadi 89,75 pada siklus II. Selain itu, berdasarkan modus dan median skor juga mengalami peningkatan. Secara keseluruhan jika diinterpretasikan dari nilai rata-rata tersebut, dapat dikatakan bahwa rata-rata intrumen tes yang dikembangkan oleh guru memiliki kategori cukup valid pada siklus I dan sangat valid pada siklus II.

Data tersebut mengindikasikan keberhasilan kegiatan pelatihan yang dilakukan dengan mengintegrasikan self assessment. Kegiatan self assessment sangat berguna untuk mengidentifikasi hal-hal yang masih belum dipahami dengan baik oleh guru. Dengan menerapkan self assessment guru akan lebih menyadari kebergunaan proses pelatihan sebagai wadah pembelajaran untuk meningkatkan kinerja diri. Hal tersebut sesuai dengan penelitian Purnamah, Nuryana, \& Puspitasari (2017) yang menunjukkan bahwa implementasi self assessment mampu secara signifikan meningkatkan kesadaran belajar siswa. Self assessment sebagai salah satu bentuk penilaian formatif berguna untuk memaksimalkan hasil pelatihan yang dilaksanakan.

Dalam pelaksanaan penelitian, kegiatan self assessment tidak hanya menuliskan hal-hal yang belum dipahami dengan baik oleh guru, namun guru diminta menuliskan hal-hal apa saja yang telah dipahami dari kegiatan pelatihan. Hal tersebut bertujuan untuk menjadi pembanding antara hasil self assessment dari guru dengan penilaian yang diberikan oleh validator sebagai gambaran kinerja kemampuan guru dalam membuat instrumen penelitian. Pada dasarnya self assessment dapat digunakan sebagai pembanding antara hasil self assessment oleh pelajar terhadap penilaian yang dilakukan oleh pengajar (Marzano, 2006).

\section{Perubahan Jumlah dan Persentase Guru berdasarkan Kriteria Kevalidan}

Data terkait perubahan jumlah dan persentase kriteria kevalidan instrumen tes yang disusun guru menampilkan jumlah dan presentase guru berdasarkan kriteria validitas untuk memaparkan hasil penelitian berdasarkan aspek kriteria kevalidan ini. Data tersebut seperti yang ditunjukkan Tabel 3.

Tabel 3. Jumlah dan Persentase Guru Berdasarkan Kriteria Kevalidan

\begin{tabular}{lll}
\hline Kriteria Validitas & \multicolumn{2}{c}{$\mathbf{N}(\%)$} \\
\cline { 2 - 3 } & Siklus I & Siklus II \\
\hline Sangat valid & - & $8(100,0 \%)$ \\
Cukup valid & $7(87,5 \%)$ & - \\
Kurang valid & $1(12,5 \%)$ & - \\
Tidak valid & - & - \\
\hline
\end{tabular}

Berdasarkan data pada Tabel 3 tersebut tampak bahwa ditinjau dari kriteria validitas, kemampuan guru dalam membuat instrumen tes semakin baik. Pada siklus I terdapat $1(12,5 \%)$ guru dengan kisi-kisi yang dirancang dalam kategori kurang valid dan $7(87,5 \%)$ guru dengan kisi-kisi yang dirancang dalam kategori cukup valid. Pada siklus II terdapat $8(100 \%)$ guru berhasil merancang kisi-kisi sebagai instrumen tes dengan kategori sangat valid.

Hasil tersebut tentu menambah temuan terhadap kegunaan self assessment. Peningkatan kemampuan guru dalam membuat instrumen tes ini karena pemberian feedback yang dilakukan dengan segera. Perlu disadari bahwa hasil penilaian pada self assessment harus dimanfaat dengan baik untuk memaksimalkan capaian tujuan pembelajaran. Pada kegiatan pelatihan ini guru harus benar-benar memahami dengan baik terkait konsep dasar penilaian, baik secara teoritis maupun praktis.

Pada pertemuan pertama, guru masih banyak keliru dalam menyusun instrumen penilaian. Beberapa hal yang menjadi masukan oleh validator adalah 
banyaknya soal dengan pengecoh yang kurang baik, penggunaan bahasa yang tidak lugas sehingga soal terkesan panjang, kesalahan dalam menyusun indikator soal, dan beberapa soal yang dirancang juga tidak sesuai dengan level kognitif yang akan diukur. Pada siklus II pelatihan dilakukan secara lebih mendalam dan difokuskan pada bagaimana menyusun kisi-kisi, dengan membahasnya secara detil. Pada awal siklus II guru diminta untuk menjelaskan hal-hal yang masih membingungkan. Pertanyaan pada self assessment siklus II ini dibuat rinci untuk menanyakan pemahaman guru pada halhal kecil yang harus diperhatikan. Hal tersebut bertujuan untuk membuat guru-guru peserta pelatihan dapat mengontrol penguasaan kompetensi yang dimiliki karena sesuai dengan menurut Thomas, Martin, \& Pleasants (2011) yang menyatakan bahwa self assessment diimpelentasikan karena memiliki tujuan untuk melatih siswa (dalam hal ini peserta pelatihan) menilai kemampuan dirinya sendiri dalam penguasaan kompetensi tertentu yang akan dibidik dalam proses belajar.

Berdasarkan hasil wawancara yang dilakukan, guru-guru memberikan pendapat bahwa self assessment berguna selama proses pelatihan. Salah satu guru mengatakan bahwa self assessment yang dicancang dengan baik dapat menjadi alternatif untuk mengatasi siswa yang belum paham terhadap materi yang disampaikan oleh guru namun malu untuk bertanya. Hal tersebut tentu bisa saja terjadi karena siswa yang tidak bertanya ketika diberi kesempatan bertanya oleh gurunya tidak dapat menjamin bahwa siswa telah benar-benar memahami materi dengan baik. Selain itu, guru lain berpendapat bahwa dirinya merasa lebih termotivasi untuk mengikuti pelatihan dengan baik karena adanya self assessment yang menurutnya adalah hal baru yang belum pernah dilakukan sebelumnya. Pembaharuan dalam pembelajaran semacam ini memang perlu dilakukan, misalnya dengan menerapkan self assessment agar siswa lebih termotivasi. Keunggulan penerapan self assessment adalah mampu memotivasi siswa dan mampu meningkatkan elaborasi antara siswa dengan guru (Ross, 2006; Thomas et al., 2011).

\section{KESIMPULAN}

Penerapan pelatihan dengan mengintegrasikan self assessment beguna untuk meningkatkan kemampuan guru dalam merancang instrumen tes. Hal tersebut diindikasikan dari peningkatan rata-rata skor guru dalam membuat instrumen soal. Selain itu berdasarkan persentase guru berdasarkan kriteria validitas juga menunjukkan peningkatan. Berdasarkan hasil wawancara yang dilakukan pada guru, guru-guru memberikan pendapat bahwa self assessment berguna dalam membantu pemahaman mereka.

Integrasi self assessment dalam kegiatan pelatihan telah menunjukkan hasil positif terhadap kemampuan guru dalam merancang instrument tes. Untuk penelitian kedepannya, integrasi self assessment dapat menjadi alternatif dalam meningkatkan kemampuan guru pada hal-hal lain, misalkan dalam membuat media pembelajaran maupun perangkat ajar. Selain itu, penelitian ini dapat dilanjutkan lebih jauh lagi sebagai penelitian eksperimental karena dalam penelitian ini masih terbatas dalam penelitian tindakan.

\section{DAFTAR RUJUKAN}

Abdul Kadir. (2015). Menyusun dan menganalisis tes hasil belajar abdul kadir. AlTa'dib, 8(2), 70-81. Retrieved from http://ejournal.iainkendari.ac.id/index.php/altadib/article/view/411/396

Akbar, S. (2013). Instrumen Perangkat Pembelajaran. Bandung: PT Remaja Rosdakarya.

Amalia, A. N., \& Widayati, A. (2012). Analisis butir soal tes kendali mutu kelas XII SMA mata pelajaran ekonomi akuntansi di kota Yogyakarta tahun 2012. Jurnal Pendidikan Akuntansi Indonesia, 10(1), 1-26. https://doi.org/10.21831/jpai.v10i1.919

Arifin, Z. (2012). Evaluasi Pembelajaran : Prinsip, Teknik dan Prosedur. Bandung: PT 
Remaja Rosdakarya.

Bhakti, S. S., Samsudin, A., Chandra, D. T., \& Siahaan, P. (2017). Developing multiplechoices test items as tools for measuring the scientific-generic skills on solar system. In AIP Conference Proceedings (Vol. 1848, p. 50010). American Institute of Physics Inc. https://doi.org/10.1063/1.4983968

Handayani, T., \& Ambar, H. (2015). Validitas Dan Reliabilitas Soal Tengah Semester Genap Kaitannya Dengan Ketercapaian Tujuan Pembelajaran Bahasa Indonesia Kelas VIIIA SMP Negeri 2 Banyudono Tahun Pelajaran 2013/2014. Surakarta.

Kemmis, S., McTaggart, R., \& Nixon, R. (2014). The Action Research Planner_Doing Critica - Stephen Kemmis (Springer). New York.

Marzano, R. J. (2006). Classroom Assessment and Grading That Work. Virginia: ASCD.

Matondang, Z. (2009). validitas dan reliabilitas suatu instrumen penelitian. Jurnal $\begin{array}{llll}\text { Tabularasa } & \text { PPS }\end{array}$ https://doi.org/10.4028/www.scientific.net/AMM.496-500.1510

Muchtar, H. (2010). Penerapan penilaian autentik dalam upaya peningkatan mutu pendidikan. Jurnal Pendidikan Penabut, 9(14), 68-75. Retrieved from http://www.bpkpenabur.or.id

Nurhardini, R. (2017). Pengaruh self dan peer assessment pada materi ekosistem terhadap berpikir aplikatif dan kritis siswa SMA. Jurnal Pendidikan Matematika Dan Sains, 5(1), 69-76. https://doi.org/10.21831/jpms.v5i1.13553

Pantiwati, Y. (2016). Hakekat Asesmen Autentik Dan Penerapannya Dalam Pembelajaran Biologi. Jurnal Edukasi Matematika Dan Sains, 1(1), 18. https://doi.org/10.25273/jems.v1i1.773

Purnamah, N. I., Nuryana, \& Puspitasari, E. (2017). Penerapan Self-Assesment untuk Menumbuhkan Kesadaran Siswa tentang Makna Belajar pada Mata Pelajaran IPS di MTs Sabilul Chalim Kec. Leuwimunding Kab. Majalengka. Jurnal Edueksos, 6(1), 65-80. Retrieved from http://www.syekhnurjati.ac.id/jurnal/index.php/edueksos/article/view/1942

Rahmawati, D. U., Jumadi, Kuswanto, H., \& Oktaba, I. A. (2020). Identification of students' misconception with isomorphic multiple choices test on the force and newton's law material. In Journal of Physics: Conference Series (Vol. 1440, p. 12052). IOP Publishing. https://doi.org/10.1088/1742-6596/1440/1/012052

Ross, J. A. (2006). The Reliability, Validity, and Utility of Self-Assessment. Practical Assessment, Research, and Evaluation, 11(11), 1-13. https://doi.org/10.7275/9wph-vv65

Salamah, U. (2018). Penjaminan mutu penilaian pendidikan. Journal Evaluasi, 2(1), 274. https://doi.org/10.32478/evaluasi.v2i1.79

Setiawan, F. (2013). Kemampuan Guru Melakukan Penilaian dalam Pembelajaran melalui Internalisasi Nilai Kejujuran pada Pembelajaran Pendidikan Kewarganegaraan. Jurnal Pendidikan IImu-IImu Sosial (JUPIIS), 5(2), 73-81. Retrieved from https://jurnal.unimed.ac.id/2012/index.php/jupiis/article/view/1116

Thomas, G., Martin, D., \& Pleasants, K. (2011). Using self-and peer-assessment to enhance students' future-learning in higher education. Journal of University Teaching \& Learning Practice, 8(1), 1-17. Retrieved from https://eric.ed.gov/?id=EJ940101

Wahyuningsih, R., Wahyuni, S., \& Lesmono, A. (2016). Pengembangan instrumen self assessment berbasis web untuk menilai sikap ilmiah pada pembelajaran fisika di SMA. Jurnal Pembelajaran Fisika, 4(4), 338-343-343. Retrieved from https://jurnal.unej.ac.id/index.php/JPF/article/view/3087

Wilujeng, T. T. R. (2014). Metode Self-Assessment sebagai Metode Alternatif dalam Melakukan Evaluasi Belajar Mahasiswa. Jurnal IImiah Bahasa Dan Sastra, 1(1), 23557083. from http://ejournal.unikama.ac.id/index.php/JIBS/article/view/334

Zahro, I. F. (2015). Penilaian dalam Pembelajaran Anak Usia Dini. Jurnal Tunas 
www.journal.unublitar.ac.id/jp

Siliwangi,

1(1),

92-111.

Vol 4 No 2, April 2020

journal.stkipsiliwangi.ac.id/index.php/tunas-siliwangi/article/view/95

http://e-

Retrieved from 